\title{
Heinänurmen säilöntämenetelmän vaikutus maidon rasvahappokoostumukseen
}

Anni Halmemies ${ }^{1,2)}$, Piia Kairenius ${ }^{1)}$, Seppo Ahvenjärvi ${ }^{1)}$, Pekka Huhtanen ${ }^{3)}$, Aila Vanhatalo ${ }^{2)}$, Vesa Toivonen ${ }^{1)}$, Kevin J. Shingfield ${ }^{1)}$

${ }^{1)}$ MTT, Kotieläintuotannon tutkimus,31600Jokioinen, etunimi.sukunimi@mtt.fi

${ }^{2}$ HY, Kotieläintieteen laitos, PL 28,00014 Helsingin yliopisto, etunimi.sukunimi@helsinki.fi

${ }^{3)}$ SLU, Department of Agricultural Research for Northern Sweden, etunimi.sukunimi@njv.slu.se

\section{Tiivistelmä}

Maito on monipuolinen rasvahappojen lähde. Maitorasvan koostumusta voidaan muokata lisäämällä haluttujen rasvahappojen saantia rehusta sekä vähentämällä tyydyttymättömien rasvahappojen biohydrogenaatiota pötsissä. Lypsylehmien rehuannoksen kuiva-aineesta yleensä 40 - 60\% on karkearehua joko tuoreena, säilörehuna tai heinänä. Karkearehun vaikutuksesta maidon rasvahappokoostumukseen tiedetään kuitenkin vähän. Nurmikasvien lehtien rasvahapoista tyypillisesti yli $50 \%$ on alfalinoleenihappoa (cis-9,cis12,cis-15 18:3) ja 10 - $20 \%$ linolihappoa (cis-9,cis-12 18:2). Tämän tutkimuksen tavoitteena oli selvittää, kuinka heinänurmen säilöntämenetelmä vaikuttaa maidon rasvahappokoostumukseen.

Kokeet tehtiin Jokioisilla Maa- ja elintarviketalouden tutkimuskeskuksessa, Kotieläintuotannon tutkimuksen koe-eläintallissa kesällä (koe 1) ja talvella (koe 2) 2005. Kummassakin kokeessa oli viisi useamman kerran poikinutta ay-lehmää. Kokeen 1 alkaessa lehmien poikimisesta oli kulunut $229 \pm 31,7$ päivää ja kokeen 2 alkaessa $53 \pm 5,3$ päivää. Kokeessa 1 oli kaksi jaksoa. Ensimmäisellä jaksolla kaikki lehmät saivat karkearehunaan niittorehua ja toisella jaksolla latokuivattua heinää. Koe 2 toteutettiin osittain toistettuna 3x3 latinalaisena neliönä. Koekäsittelyinä olivat heinä, painorehu sekä hapolla säilötty rehu. Jakson pituus oli kummassakin kokeessa 14 päivää. Kokeiden 1 ja 2 säilörehut ja heinä niitettiin samasta timotei-nurminatakasvustosta 15.6.2005. Myös kokeen 1 niittorehu oli tästä kasvustosta. Lehmät saivat karkearehua vapaasti ja väkirehua $7 \mathrm{~kg} /$ päivä (koe 1) tai $9 \mathrm{~kg} /$ päivä (koe 2).

Karkearehun kuivaaminen ei vaikuttanut karkearehun syöntiin eikä maito- ja valkuaistuotokseen, mutta se vähensi rasvatuotosta. Lehmät söivät enemmän säilörehua kuin heinää (keskimäärin 13,1 vs. 11,8 $\mathrm{kg} \mathrm{ka} / \mathrm{pv}$ ). Säilörehua saaneet lehmät myös tuottivat enemmän maitoa ja rasvaa kuin heinää saaneet, mutta valkuaistuotokseen säilöntämenetelmällä ei ollut vaikutusta. Säilöntäaineen käyttö lisäsi säilörehun syöntiä $(+1,6 \mathrm{~kg} \mathrm{ka} / \mathrm{pv})$ sekä rasva - ja valkuaistuotosta, mutta se ei vaikuttanut maitotuotokseen.

Niittorehua saaneiden maitorasva sisälsi vähemmän tyydyttyneitä ja enemmän tyydyttymättömiä rasvahappoja kuin heinää saaneiden maitorasva. Niittorehu lisäsi mm. öljyhapon (cis-9 18:1), konjugoidun linolihapon (CLA), linolihapon ja alfalinoleenihapon osuutta maitorasvassa heinään verrattuna. Maitorasvan tyydyttyneiden ja tyydyttymättömien rasvahappojen kokonaispitoisuuksissa ei ollut eroa heinä- ja säilörehuruokintojen välillä. Säilörehuruokinta vähensi suuntaa-antavasti alfalinoleenihapon ja lisäsi merkitsevästi steariinihapon (18:0), trans-18:1:n ja CLA:n osuutta maitorasvassa heinäruokintaan verrattuna. Erot maitorasvan koostumuksessa olivat pienet säilörehuruokintojen välillä. Säilöntäaineen käyttö ei vaikuttanut maitorasvan alfalinoleenihappopitoisuuteen, mutta lisäsi merkitsevästi steariinihapon ja trans18:1 rasvahappojen sekä suuntaa-antavasti CLA:n osuutta maitorasvassa.

Asiasanat: lypsylehmä, karkearehu, maitorasva, tyydyttymättömät rasvahapot, CLA, trans-rasvahapot 


\section{Johdanto}

Maito on monipuolinen rasvahappojen lähde, sillä siitä on tunnistettu yli 500 erilaista rasvahappoa. Maidon rasvahappokoostumusta voidaan muokata lisäämällä haluttujen rasvahappojen saantia rehusta sekä vähentämällä tyydyttymättömien rasvahappojen biohydrogenaatiota pötsissä. Glasserin ym. (2008) mukaan jopa $87 \%$ rehun monityydyttymättömistä C18-rasvahapoista biohydrogenoituu pötsissä. Biohydrogenaatiossa tyydyttymättömät rasvahapot pelkistyvät, kun kaksoissidoksiin liittyy vetyä $\left(\mathrm{H}_{2}\right)$.

Lypsylehmien rehuannoksen kuiva-aineesta yleensä 40 - $60 \%$ on karkearehua joko tuoreena, säilörehuna tai heinänä, mutta karkearehun, ja erityisesti sen säilönnän, vaikutuksesta maidon rasvahappokoostumukseen tiedetään vähän. Nurmikasvien lipidit ovat märehtijöiden rehun halvin tyydyttymättömien rasvahappojen lähde. Lisäksi lehtien rasvahapoista tyypillisesti yli $50 \%$ on alfalinoleenihappoa (cis-9,cis12,cis-15 18:3) ja 10 - $20 \%$ linolihappoa (cis-9,cis-12 18:2) (Morand-Fhrer ja Tran 2001). Kuivattuun tai säilöttyyn nurmirehuun verrattuna laidun- tai niittorehuruokinta vähentää maitorauhasen de novo -synteesissä muodostuvien lyhyt (C4-C10) - ja keskipitkäketjuisten (C12-C14) rasvahappojen sekä palmitiinihapon (16:0) pitoisuutta ja lisää cis-18:1 rasvahappojen, konjugoidun linolihapon (engl. conjugated linoleic acid; CLA) ja alfalinoleenihapon pitoisuutta maitorasvassa (Chilliard ym. 2001; Dewhurst ym. 2006). Tämän tutkimuksen tavoitteena oli selvittää, kuinka heinänurmen säilöntämenetelmä (heinä, painorehu ja muurahaishapolla säilötty rehu) vaikuttaa maidon rasvahappokoostumukseen.

\section{Aineisto ja menetelmät}

Tutkimuksessa oli kaksi osakoetta, jotka tehtiin Jokioisilla Maa- ja elintarviketalouden tutkimuskeskuksessa, Kotieläintuotannon tutkimuksen koe-eläintallissa kesällä (koe 1) ja talvella (koe 2) 2005. Kummassakin kokeessa oli viisi useamman kerran poikinutta ay-lehmää. Kokeen 1 alkaessa lehmien poikimisesta oli kulunut $229 \pm 31,7$ päivää ja kokeen 2 alkaessa $53 \pm 5,3$ päivää. Lehmien elopaino oli kokeen 1 alkaessa keskimäärin $605 \pm 25,7 \mathrm{~kg}$ ja kokeen 2 alkaessa keskimäärin $617 \pm 25,8 \mathrm{~kg}$. Koejakson pituus oli kummassakin kokeessa 14 päivää. Kokeessa 1 oli kaksi koejaksoa. Ensimmäisellä koejaksolla kaikki lehmät saivat karkearehunaan niittorehua ja toisella koejaksolla latokuivattua heinää. Koe 2 toteutettiin osittain toistettuna 3x3 latinalaisena neliönä. Koekäsittelyinä olivat heinä, painorehu sekä muurahaishapolla säilötty rehu.

Kokeiden 1 ja 2 säilörehut ja heinä niitettiin samasta timotei-nurminatakasvustosta 15.6.2005. Kokeen 1 niittorehu oli myös tästä kasvustosta ja sitä korjattiin lehmille päivittäin. Heinää varten nurmea esikuivattiin pellolla 4 päivää (kuiva-aineeseen $750 \mathrm{~g} / \mathrm{kg}$ ), minkä jälkeen se paalattiin pikkupaaleihin ja siirrettiin latokuivuriin. Säilörehun korjuuta varten nurmea esikuivattiin pellolla $3-4 \mathrm{~h}$, minkä jälkeen se korjattiin tarkkuussilppurilla ja säilöttiin laakasiiloihin joko ilman säilöntäainetta (painorehu) tai muurahaishappopohjaista säilöntäainetta käyttäen (6 1/tonni rehua; AIV2 Plus, Kemira Oyj). Koerehujen koostumus on esitetty taulukossa 1 . Lehmät saivat karkearehua vapaasti ja ohrapitoista väkirehua $7 \mathrm{~kg} / \mathrm{päivä}$ (koe 1) tai $9 \mathrm{~kg} /$ päivä (koe 2) neljässä yhtä suuressa erässä.

Lehmien syönti ja maitotuotos mitattiin päivittäin koko kokeen ajan. Lehmät lypsettiin klo 7.00 ja 16.45. Suhteelliset maitonäytteet maidon valkuais- ja rasvapitoisuuden sekä rasvahappokoostumuksen määrittämiseksi otettiin jokaisen jakson viimeisellä viikolla neljältä peräkkäiseltä lypsykerralta. Valkuais- ja rasvapitoisuuden määritystä varten maitonäytteet säilöttiin Bronopol-tableteilla. Rasvahappomääritystä varten maidot $(500 \mathrm{ml})$ pakastettiin $\left(-20^{\circ} \mathrm{C}\right)$ ilman säilöntäainetta.

Rehunäytteet analysoitiin MTT Kotieläintuotannon tutkimuksen laboratoriossa standardimenetelmin. Rasvan uutto, triglyseridien transmetylaatio ja vapaiden rasvahappojen metylaatio rasvahappojen metyyliestereiksi (FAME) rehuista ja maidosta tehtiin Shingfieldin ym. (2003) mukaan. Rasvahappojen metyyliesterit eroteltiin kaasukromatografissa CP-Sil 88 kapillaarikolonnilla, käyttäen vetyä kantajakaasuna (Shingfield ym. 2003). Rasvahapot tunnistettiin pääasiassa vertaamalla niiden retentioaikoja metyloitujen rasvahappojen standardeihin (GLC 463 ja 606, N-21/23/24-M, U-37/39/43/54/64/85/87-M, Nu-Check-Prep, Elysian, MN; L-8404, H-6389/6639 ja O-4129 Sigma-Aldrich, Helsinki, Finland). Tulosten laskennassa käytettiin teoreettisia vastekertoimia (Wolff ym. 1995). Konjugoidun linolihapon isomeerit määritettiin nestegromatografilla, jossa oli neljä peräkkäistä ChromSpher Lipids-kolonnia. Ajoliuoksena käytettiin 0,1\% asetonitriiliä (ACN) heptaanissa virtausnopeudella $1 \mathrm{ml} / \mathrm{min}$ (Shingfield ym. 2003). Isomeerit tunnistettiin vertaamalla näytteiden kromatogrammeja metyloitujen CLA-isomeeristandardien kromatogrammeihin (Shingfield ym. 2005). Maidon rasva- ja valkuaispitoisuus määritettiin infrapuna-analysaattorilla.

Tulokset analysoitiin tilastollisesti SAS GLM - proseduuria käyttäen. Kokeen 1 tilastollisessa mallissa luokittelevina muuttujina olivat eläin ja karkearehukäsittely ja kokeessa 2 eläin, jakso ja karkearehukäsittely. 
Eläin oli kummassakin mallissa satunnaisena tekijänä. Virhetekijälle jäi vapausasteita 4 kokeessa 1 ja 6 kokeessa 2. Kokeen 1 tulokset testattiin parittaisin t-testein ja kokeen 2 tulokset ortogonaalisin kontrastein: 1) heinä vs. säilörehut (säilöntämenetelmä) ja 2) painorehu vs. muurahaishapolla säilötty rehu (säilöntäaine).

\section{Tulokset ja tulosten tarkastelu}

Lehmät söivät koko väkirehuannoksensa kummassakin kokeessa. Karkearehun kuivaaminen ei vaikuttanut $(\mathrm{P}>0,10)$ karkearehun syöntiin (keskimäärin $11,5 \mathrm{~kg} \mathrm{ka} / \mathrm{pv}$ ) eikä maito- ja valkuaistuotokseen, mutta se vähensi $(\mathrm{P}<0,05)$ rasvatuotosta (taulukko 2, koe 1). Rasvahappojen kokonaissaanti oli 1,5-kertaa suurempi $(\mathrm{P}<0,01)$ niittorehu- kuin heinäruokinnassa (taulukko 2, koe 1), sillä huomattava osa rehun monityydyttymättömistä rasvahapoista hapettuu peltokuivauksen aikana. Etenkin alfalinoleenihappo on altis hapettumiselle (Dewhurst ym. 2006). Kokeessa 2 lehmät söivät enemmän $(\mathrm{P}<0,05)$ säilörehuja kuin heinää (keskimäärin 13,1 vs. 11,8 kg ka/pv). Säilörehua saaneet lehmät myös tuottivat enemmän $(\mathrm{P}<0,05)$ maitoa ja rasvaa kuin heinää saaneet, mutta valkuaistuotokseen säilöntämenetelmällä ei ollut vaikutusta $(\mathrm{P}>0,10$; taulukko 2, koe 2). Säilöntäaineen käyttö lisäsi $(\mathrm{P}<0,05)$ säilörehun syöntiä $(+1,6 \mathrm{~kg} \mathrm{ka} / \mathrm{pv})$ sekä rasva- ja valkuaistuotosta, mutta se ei vaikuttanut maitotuotokseen $(\mathrm{P}>0,10)$.

Karkearehun kuivaus muutti huomattavasti maidon rasvahappokoostumusta (taulukot 2 ja 3, koe 1). Niittorehua saaneiden lehmien maitorasva sisälsi vähemmän $(\mathrm{P}<0,05)$ tyydyttyneitä ja enemmän $(\mathrm{P}<0,05)$ kerta- ja monityydyttymättömiä rasvahappoja kuin heinää saaneiden lehmien maitorasva. Niittorehuruokinta vähensi $(\mathrm{P}<0,05)$ erityisesti keskipitkäketjuisten $(\mathrm{C} 12-\mathrm{C} 16)$ rasvahappojen osuutta maidon kokonaisrasvahapoista heinäruokintaan verrattuna. Numeerisesti lasku oli suurin maitorasvan palmitiinihappopitoisuudessa (16:0). Lähes kaikki maitorasvan lyhytketjuiset (C4-C10) rasvahapot ja suuri osa keskipitkäketjuisista rasvahapoista ovat peräisin maitorauhasen de novo -synteesistä (Baer 1996). Tyydyttymättömien C18-rasvahappojen huomattavasti suurempi saanti niittorehu- kuin heinäruokinnassa selittänee de novo -rasvahappojen pitoisuuden vähenemistä maitorasvassa niittorehua annettaessa, sillä pitkäketjuiset, monityydyttymättömät rasvahapot inhiboivat maitorauhasen de novo -synteesiä (Chilliard 2000).

Niittorehuruokinta lisäsi $(\mathrm{P}<0,05)$ linoli- ja alfalinoleenihapon osuutta maitorasvassa heinäruokintaan verrattuna (taulukko 2, koe 1). Alfalinoleenihapon saanti oli yli 2,5-kertainen $(\mathrm{P}<0,01)$ niittorehuruokinnassa heinäruokintaan verrattuna, mikä selittänee sen suurempaa pitoisuutta myös maitorasvassa. Alfalinoleenihapon hydrogenaatiotappiot pötsissä ovat kuitenkin suuremmat tuoreesta rehusta kuin heinästä (Boufaïed ym. 2003). Niittorehua saaneiden lehmien maitorasva sisälsi heinää saaneita enemmän $(\mathrm{P}<0,05)$ cis-12 18:1, cis-15 18:1 ja trans-18:1 -rasvahappoja sekä trans-11,cis-15 18:2 ja CLA:ta (taulukot 2 ja 3, koe 1), joita muodostuu linoli- ja/tai alfalinoleenihapon biohydrogenoituessa pötsissä (Harfoot ja Hazlewood 1988; Chilliard ym. 2007). Niittorehuruokinta lisäsi trans-rasvahapoista etenkin maitorasvan vakseenihappopitoisuutta (trans-11 18:1) heinäruokintaan verrattuna (taulukko 3, koe 1). Transrasvahappojen kokonaispitoisuuden lisäys $(\mathrm{P}<0,01)$ niittorehuruokinnassa oli kuitenkin numeerisesti pieni heinäruokintaan verrattuna (taulukko 2, koe 1). Maitorasvan cis-9,trans-11 CLA-pitoisuus oli 1,7-kertaa suurempi niittorehu- kuin heinäruokinnassa (taulukko 3, koe 1). Huomattava osa vakseenihaposta desaturoituu maitorauhasessa cis-9,trans-11 CLA:ksi, kun desaturaasientsyymi (EC 1.14.99.5) liittää vakseenihappoon $\Delta 9$-kaksoissidoksen. (Griinari ja Bauman 1999). Lisäksi linolihapon saanti oli huomattavasti suurempi $(\mathrm{P}<0,01)$ niittorehu- kuin heinäruokinnassa ja cis-9,trans-11 CLA on yksi linolihapon biohydrogenaation päävälituotteista (Harfoot ja Hazlewood 1998).

Niittorehua saaneiden lehmien maitorasva sisälsi heinää saaneiden maitorasvaa enemmän $(\mathrm{P}<0,01)$ steariinihappoa (18:0) (taulukko 2, koe 1), joka on tyydyttymättömien C18-rasvahappojen biohydrogenaation lopputuote, sekä öljyhappoa (cis-9 18:1) (taulukko 3, koe 1; $\mathrm{P}<0,05$ ). Öljyhapon saanti oli suurempi niittorehu- kuin heinäruokinnassa (taulukko 2 , koe $1 ; \mathrm{P}<0,01$ ). Rehujen öljyhappopitoisuus selittää vain osan maidon öljyhappopitoisuuden noususta, koska noin $40 \%$ maitorauhasen ottamasta steariinihaposta desaturoituu maitorauhasessa öljyhapoksi (Chilliard ym. 2000). Lehmät söivät numeerisesti vähemmän niittorehua kuin heinää $(-1,6 \mathrm{~kg} \mathrm{ka} / \mathrm{pv})$, mutta tuottivat numeerisesti enemmän maitoa $(+1,4 \mathrm{~kg} / \mathrm{pv})$, joten niiden energiatase on todennäköisesti ollut pienempi kuin heinää saaneiden. Negatiivisessa energiataseessa olevat lehmät purkavat rasvavarastojaan, mikä myös lisää steariini- ja öljyhapon osuutta maitorasvassa (Chilliard 2001).

Tyydyttyneiden ja tyydyttymättömien rasvahappojen kokonaispitoisuuksissa ei ollut eroa $(\mathrm{P}>0,05)$ säilörehu- ja heinäruokintojen välillä (taulukko 2, koe 2). Vaikka alfalinoleenihapon saanti oli 3,3-kertaa suurempi $(\mathrm{P}<0,001)$ säilörehu- kuin heinäruokinnassa, säilörehua saaneiden lehmien maitorasva sisälsi 
suuntaa-antavasti vähemmän $(\mathrm{P}<0,10)$ alfalinoleenihappoa kuin heinää saaneiden lehmien maitorasva. Säilörehuruokinta vähensi $(\mathrm{P}<0,01)$ myös maitorasvan linolihappopitoisuutta heinäruokintaan verrattuna. Säilörehua saaneiden lehmien maitorasva sisälsi sen sijaan heinää saaneiden maitorasvaa enemmän $(\mathrm{P}<0,05)$ alfalinoleeni- ja/tai linolihapon biohydrogenaatiossa syntyviä rasvahappoja, kuten steariinihappoa, cis-15 18:1, trans-18:1 ja CLA:ta (taulukkot 2 ja 3, koe 2) (Chilliard ym. 2007). Alfalinoleenihapon ja linolihapon onkin havaittu biohydrogenoituvan nopeammin ja suuremmassa määrin säilörehusta kuin heinästä (Boufaïed ym. 2003). Säilörehuruokinta vähensi $(\mathrm{P}<0,05)$ maitorauhasen de novo-synteesistä osittain tai kokonaan peräisin olevien 12:0- ja 14:0-rasvahappojen pitoisuutta ja lisäsi $(\mathrm{P}<0,001)$ 4:0-pitoisuutta heinäruokintaan verrattuna.

Erot maidon rasvahappokoostumuksessa olivat pienet säilörehuruokintojen välillä. Säilöntäaineen käyttö ei vaikuttanut maitorasvan linoli- ja alfalinoleenihappopitoisuuteen (taulukko 2, koe 2), mutta se lisäsi $(\mathrm{P}<0,05)$ niiden biohydrogenaatiosta peräisin olevien rasvahappojen, kuten steariinihapon, vakseenihapon, trans-11,cis-15 18:2:n ja trans-11,cis-13 CLA:n, pitoisuutta maitorasvassa (taulukot 2 ja 3, koe 2).

\section{Johtopäätökset}

Karkearehun kuivaaminen ei vaikuttanut syöntiin eikä maitotuotokseen, mutta se vähensi rasvatuotosta. Niittorehua saaneiden lehmien maitorasva sisälsi vähemmän tyydyttyneitä ja enemmän tyydyttymättömiä rasvahappoja, kuten alfalinoleenihappoa ja CLA:ta, kuin heinää saaneiden maitorasva. Lehmät söivät enemmän säilörehua kuin heinää ja säilörehua saaneet lehmät tuottivat myös enemmän maitoa ja rasvaa kuin heinää saaneet. Säilöntäaineen käyttö lisäsi säilörehun syöntiä ja rasvatuotosta, mutta se ei vaikuttanut maitotuotokseen. Eri säilöntämenetelmien (heinä, painorehu, muurahaishapolla säilötty rehu) väliset erot maitorasvan koostumuksessa olivat numeerisesti pieniä.

\section{Kiitokset}

Tämä tutkimus on osa Euroopan unionin kuudennen puiteohjelman mukaista Lipgene-hanketta (2004-2009, www.ucd.ie/lipgene/). 


\section{Kirjallisuus}

Baer, R.J. 1996. Production and utilization of dairy cow's milk and products with increased unsaturated fatty acids. Teoksessa: Progress in Dairy Science. Phillips, C.J.C. (toim.). New York. CAB International. ss. 247-261.

Boufaïed, H., Chouinard, G.F., Tremblay, H.W., Petit, H.V., Michaud, R. \& Bélanger, G. 2003. Fatty acids in forages. II. In vitro ruminal biohydrogenation of linolenic and linoleic acids from timothy. Canadian Journal of Animal Science 83: 513-522.

Chilliard,Y., Ferlay, A., Mansbridge, R.M. \& Doreau, M. 2000. Ruminant milk fat plasticity: nutritional control of saturated, polyunsaturated, trans and conjugated acids. Annales de Zootechnologie. 49:181-205.

Chilliard, Y., Ferlay, A. \& Doreau, M. 2001. Effect of different types of forages, animal fat and marine oil in cow's diet on milk fat secretion and composition, especially conjugated linoleic acid (CLA) and polyunsaturated fatty acids. Livestock Production Science 70: 31-48.

Chilliard, Y., Glasser, F., Ferlay, A., Bernard, L., Ruel, J. \& Doreau, M. 2007. Diet, rumen biohydrogenation and nutritional quality of cow and goat milk. European Journal of Lipid Science and Technolology 109: 826-855.

Dewhurst, R.J., Shingfield, K.J., Lee, M.R.F. \& Scollan, N.D. 2006. Increasing the concentrations of beneficial fatty acids in milk produced by dairy cows in high-forage systems. Animal Feed Science and Technology 131:168-206.

Glasser, F., Schmidely, P., Sauvant, D. \& Doreau, M. 2008. Digestion of fatty acids in ruminants: a meta-analysis of flows and variation factors: 2. C18 fatty acids. Animal 2: 691-704.

Griinari, J.M. \& Bauman, D.E. 1999. Biosynthesis of Conjugated Linoleic Acid and Its Incorporation into Meat and Milk in Ruminants. Teoksessa: Advances in Conjugated Linoleic Acid Research. Vol. 1. M.P. Yurawecz, M.M. Mossoba, J.K.G. Kramer, M.W. Pariza ja G.J. Nelson, (toim.). AOCS Press. Champaign, Illinois. ss. 180-200.

Harfoot, C.G. \& Hazlewood, G.P. 1988. Lipid metabolism in the rumen. Teoksessa: The Rumen Microbial Ecosystem. P.N. Hobson (toim.). Elsevier Applied Sci. Publ., London, United Kingdom. ss. 285-322.

Morand-Fehr, P. \& Tran, G. 2001. La fraction lipidique des aliments et les corps utilisés en alimentation animale. INRA Production animales 14(5): 285-302.

Shingfield, K.J., Ahvenjärvi, S., Toivonen, V., Ärölä, A., Nurmela, K.V.V., Huhtanen, P. \& Griinari, J.M. 2003. Effect of dietary fish oil on biohydrogenation of fatty acids and milk fatty acid content in cows. Animal Science 77 : 165-179.

Shingfield, K.J., Reynolds, C.K., Lupoli, B., Toivonen, V., Yurawecz, M.P., Delmonte, P., Griinari, J.M., Grandison, A.S. \& Beever, D.E. 2005. Effect of forage type and proportion of concentrate in the diet on milk fatty acid composition in cows given sunflower oil and fish oil. Animal Science 80:225-238.

Wolff, R.L., Bayard, C.C. \& Fabien, R.J. 1995. Evaluation of sequential methods for the determination of butterfat fatty acid composition with emphasis on trans-18:1 acids. Application to the study of seasonal variations in french butters. Journal of the American Oil Chemists' Society 72:1471-1483.

Taulukko 1. Koerehujen koostumus.

\begin{tabular}{|c|c|c|c|c|c|c|c|}
\hline & \multicolumn{3}{|c|}{ Koe 1} & \multicolumn{4}{|c|}{ Koe 2} \\
\hline & Niittorehu & Heinä & Väkirehu & Heinä & Painorehu ${ }^{1}$ & Happorehu $^{2}$ & Väkirehu \\
\hline Kuiva-aine, $\mathrm{g} / \mathrm{kg}$ & 184 & 870 & 889 & 838 & 238 & 243 & 881 \\
\hline \multicolumn{8}{|l|}{ Kuiva-aineessa, $\mathrm{g} / \mathrm{kg}$} \\
\hline Tuhka & 75,2 & 42,5 & 80,3 & 70,9 & 82,8 & 77,1 & 80,5 \\
\hline Raakavalkuainen & 137 & 135 & 169 & 138 & 156 & 150 & 165 \\
\hline NDF-kuitu & 599 & 623 & 238 & 628 & 543 & 538 & 268 \\
\hline Vesiliuk. hiilihydraatit & 122 & 104 & & 108 & 17.5 & 42.8 & \\
\hline In vitro OA:n sulavuus & 798 & 764 & & 711 & 751 & 757 & \\
\hline
\end{tabular}

${ }^{1)}$ Säilönnällinen laatu: pH 4,21; (g/kg KA) maitohappo (90,8), etikkahappo (36,0), propionihappo $(1,15)$, voihappo $(3,51) ;(\mathrm{g} / \mathrm{kg} \mathrm{N})$ ammoniumtyppi $(95,2)$

${ }^{2)}$ Säilönnällinen laatu: $\mathrm{pH} 3,99$; (g/kg KA) maitohappo $(57,1)$, etikkahappo $(23,5)$, propionihappo $(0,16)$, voihappo $(1,64) ;(\mathrm{g} / \mathrm{kg} \mathrm{N})$ ammoniumtyppi $(47,9)$ 
Taulukko 2. Heinänurmen säilöntämenetelmän vaikutus ravintoaineiden saantiin ja maitotuotokseen sekä maidon koostumukseen.

\begin{tabular}{|c|c|c|c|c|c|c|c|c|c|c|}
\hline & \multicolumn{4}{|c|}{ Koe 1} & \multicolumn{6}{|c|}{ Koe 2} \\
\hline & \multirow[b]{2}{*}{$\begin{array}{l}\text { Niitto- } \\
\text { rehu }\end{array}$} & \multirow[b]{2}{*}{ Heinä } & \multirow[b]{2}{*}{ SEM } & \multirow[b]{2}{*}{$P^{l}$} & \multirow[b]{2}{*}{ Heinä } & \multirow{2}{*}{$\begin{array}{c}\text { Paino- } \\
\text { rehu }\end{array}$} & \multirow{2}{*}{$\begin{array}{c}\text { Happo- } \\
\text { rehu }\end{array}$} & \multirow[b]{2}{*}{ SEM } & \multicolumn{2}{|c|}{$P^{2}$} \\
\hline & & & & & & & & & $\begin{array}{c}\text { Säilöntä- } \\
\text { menetelmä }\end{array}$ & $\begin{array}{c}\text { Säilöntä- } \\
\text { aine }\end{array}$ \\
\hline \multicolumn{11}{|l|}{$\overline{\text { Syönti }}$} \\
\hline Karkearehun KA, kg/d & 10,7 & 12,3 & 0,68 & & 11,8 & 12,3 & 13,9 & 0,38 & $*$ & * \\
\hline Dieetin KA, kg/d & 16,5 & 18,4 & 0,71 & & 19,8 & 20,2 & 21,8 & 0,38 & $*$ & $*$ \\
\hline \multicolumn{11}{|l|}{ Saanti } \\
\hline $\mathrm{NDF}, \mathrm{kg} / \mathrm{d}$ & 7,82 & 9,10 & 0,382 & $\circ$ & 9,59 & 8,80 & 9,54 & 0,219 & & $\circ$ \\
\hline Typpi, g/d & 402 & 425 & 15,1 & & 472 & 516 & 544 & 9,80 & $* *$ & $\circ$ \\
\hline cis-9 18:1, g/d & 48,7 & 41,0 & 1,17 & $* *$ & 62,0 & 68,4 & 69,1 & 0,64 & $* * *$ & \\
\hline cis-9,cis-12 18:2, g/d & 112 & 88,6 & 3,42 & $* *$ & 121 & 149 & 153 & 3,3 & $* * *$ & \\
\hline cis $-9, c i s-12, c i s-1518: 3 \mathrm{~g} / \mathrm{d}$ & 147 & 58,3 & 8,71 & $* *$ & 55,1 & 175 & 187 & 11,64 & $* * *$ & \\
\hline$\sum$ Rasvahapot, g/d & 427 & 277 & 17,6 & $* *$ & 340 & 538 & 559 & 20,9 & $* * *$ & \\
\hline \multicolumn{11}{|l|}{ Tuotos } \\
\hline Maito, kg/d & 24,7 & 23,3 & 0,79 & & 29,3 & 31,2 & 32,7 & 0,79 & $*$ & \\
\hline $\mathrm{EKM}, \mathrm{kg} / \mathrm{d}$ & 26,3 & 24,4 & 0,49 & $\circ$ & 28,5 & 29,8 & 32,4 & 0,40 & $* *$ & $* *$ \\
\hline Rasva, g/d & 1102 & 1010 & 17,9 & $*$ & 1129 & 1200 & 1320 & 13,1 & $* * *$ & $* * *$ \\
\hline Valkuainen, g/d & 887 & 846 & 34,6 & & 908 & 904 & 1012 & 27,3 & & $*$ \\
\hline \multicolumn{11}{|l|}{ Pitoisuus maidossa } \\
\hline Rasva, g/kg & 44,9 & 43,8 & 1,70 & & 38,3 & 38,8 & 40,4 & 1,27 & & \\
\hline Valkuainen, $\mathrm{g} / \mathrm{kg}$ & 36,2 & 36,8 & 0,35 & & 31,1 & 29,5 & 31,1 & 0,89 & & \\
\hline \multicolumn{11}{|c|}{ Maitorasvan koostumus, g/lo0g rasvahappoja } \\
\hline $4: 0$ & 3,18 & 3,14 & 0,098 & & 3,55 & 3,94 & 4,26 & 0,059 & $* * *$ & $* *$ \\
\hline $6: 0$ & 1,90 & 2,05 & 0,085 & & 2,26 & 2,36 & 2,48 & 0,030 & $* *$ & $* *$ \\
\hline $8: 0$ & 1,19 & 1,31 & 0,062 & & 1,36 & 1,37 & 1,43 & 0,021 & & $\circ$ \\
\hline 10:0 & 2,76 & 3,27 & 0,134 & $\circ$ & 3,26 & 3,09 & 3,09 & 0,068 & $\circ$ & \\
\hline $12: 0$ & 3,29 & 4,17 & 0,179 & $*$ & 3,92 & 3,66 & 3,58 & 0,093 & $*$ & \\
\hline $14: 0$ & 11,0 & 13,0 & 0,51 & $*$ & 13,2 & 12,6 & 12,4 & 0,17 & $*$ & \\
\hline $16: 0$ & 27,2 & 36,8 & 1,08 & $* *$ & 36,8 & 36,7 & 34,9 & 0,55 & & $\circ$ \\
\hline$\sum$ cis $16: 1$ & 2,09 & 2,25 & 0,076 & & 1,83 & 1,66 & 1,53 & 0,048 & $* *$ & $\circ$ \\
\hline$\sum$ trans $16: 1$ & 0,66 & 0,50 & 0,007 & $* * *$ & 0,48 & 0,43 & 0,44 & 0,011 & $*$ & \\
\hline$\sum 16: 1$ & 2,75 & 2,75 & 0,070 & & 2,31 & 2,10 & 1,97 & 0,053 & $* *$ & \\
\hline $18: 0$ & 9,57 & 6,27 & 0,427 & $* *$ & 8,25 & 9,05 & 9,82 & 0,204 & $* *$ & $*$ \\
\hline$\sum$ cis $18: 1$ & 24,2 & 15,2 & 1,87 & $*$ & 12,8 & 12,7 & 13,3 & 0,51 & & \\
\hline$\sum$ trans $18: 1$ & 2,51 & 1,55 & 0,049 & $* * *$ & 2,46 & 3,00 & 3,24 & 0,065 & $* * *$ & $*$ \\
\hline$\sum 18: 1$ & 26,8 & 17,0 & 1,83 & $*$ & 15,2 & 15,7 & 16,5 & 0,54 & & \\
\hline$\sum 18: 2^{3}$ & 2,06 & 1,63 & 0,044 & $* *$ & 1,63 & 1,54 & 1,66 & 0,055 & & \\
\hline $\mathrm{CLA}^{4}$ & 0,66 & 0,38 & 0,059 & $*$ & 0,33 & 0,36 & 0,41 & 0,017 & $*$ & $\circ$ \\
\hline cis-9,cis-12,cis-15 18:3 & 0,66 & 0,50 & 0,009 & $* * *$ & 0,45 & 0,42 & 0,43 & 0,011 & $\circ$ & \\
\hline \multicolumn{11}{|l|}{ Yhteenveto } \\
\hline$\sum C 4-C 14$ & 25,1 & 29,3 & 1,15 & $\circ$ & 29,6 & 29,2 & 29,3 & 0,33 & & \\
\hline$\sum$ Trans-rasvahapot & 4,03 & 2,67 & 0,075 & $* *$ & 3,75 & 4,40 & 4,77 & 0,106 & $* * *$ & $*$ \\
\hline$\sum$ Tyydyttyneet & 63,8 & 74,2 & 1,69 & $*$ & 76,8 & 76,5 & 75,4 & 0,69 & & \\
\hline$\sum$ Kertatyydyttymättömät & 32,0 & 22,5 & 1,70 & $*$ & 20,1 & 20,3 & 20,9 & 0,61 & & \\
\hline$\sum$ Monityydyttymättömät & 3,94 & 3,00 & 0,048 & $* * *$ & 2,81 & 2,71 & 2,88 & 0,068 & & \\
\hline $\begin{array}{l}\text { Karkearehun kuivaamisen } \\
\text { 2) Säilöntämenetelmän tilastc } \\
=\text { heinä vs. säilörehut, Säilön } \\
* \mathrm{P}<0,05, * * \mathrm{P}<0,01, * * * \mathrm{P}< \\
{ }^{3)} \text { Ilman konjugoitua linoliha } \\
\text { 4) Konjugoitu linolihappo }\end{array}$ & $\begin{array}{l}\text { tilastollin } \\
\text { tollinen m } \\
\text { ntäaine = } \\
<0,001, \text { o } \\
\text { appoa }\end{array}$ & $\begin{array}{l}\text { nen merki } \\
\text { erkitsevy } \\
\text { painoreh } \\
\mathrm{P}<0,10 \text {, }\end{array}$ & $\begin{array}{l}\text { sevyys (n } \\
\text { s testattiir } \\
\text { vs. happo } \\
\text { s tyhjä P }\end{array}$ & $\begin{array}{l}0 ; \mathrm{df}= \\
\text { rtogo } \\
\text { hu. } \\
10 .\end{array}$ & sin kontr & stein & $15 ; \mathrm{df}=$ & Säilönt & tämenete & \\
\hline
\end{tabular}


Taulukko 3. Heinänurmen säilöntämenetelmän vaikutus maitorasvan 18:1- ja 18:2-koostumukseen.

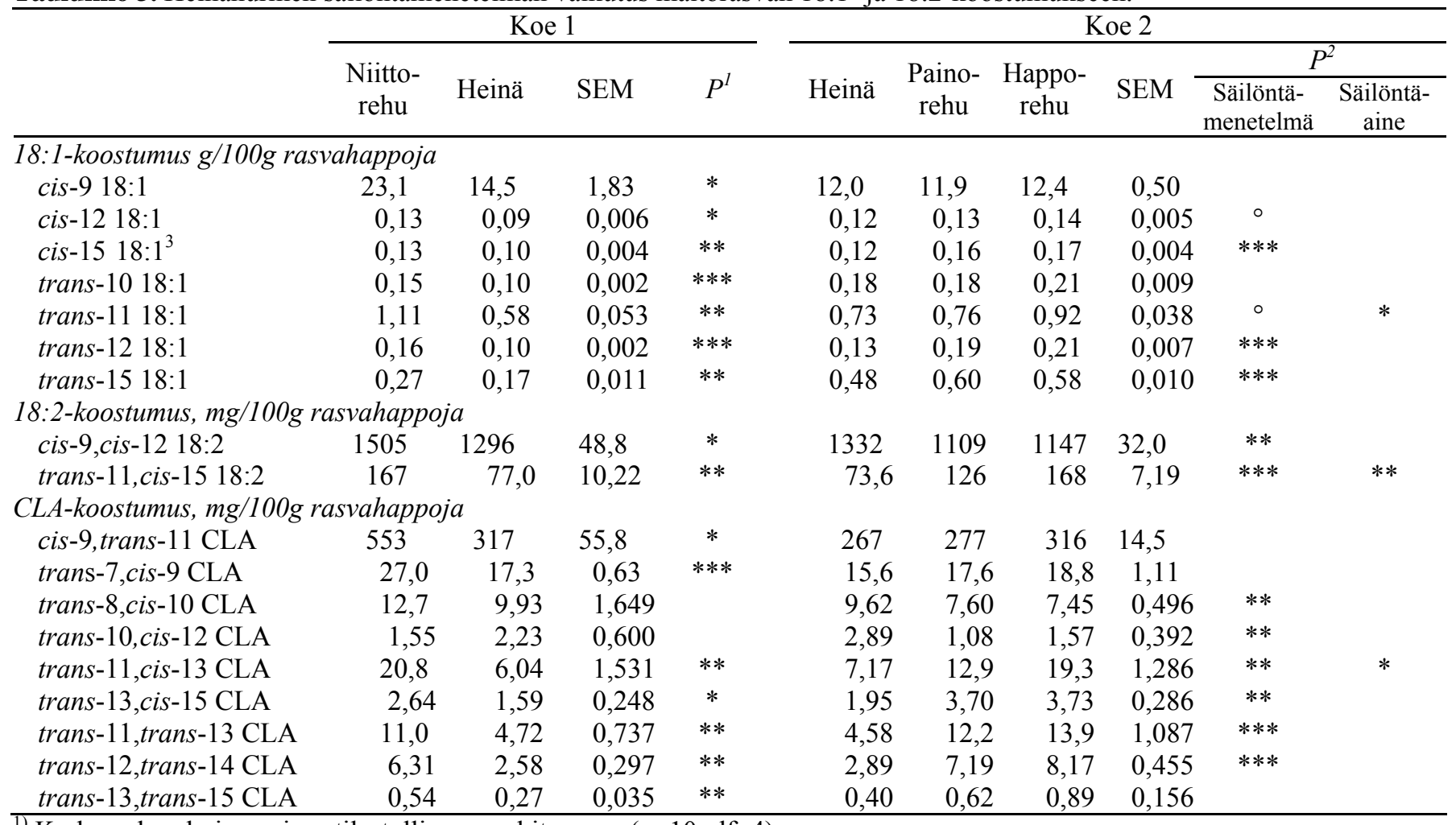

${ }^{1)}$ Karkearehun kuivaamisen tilastollinen merkitsevyys $(\mathrm{n}=10 ; \mathrm{df}=4)$.

2) Säilöntämenetelmän tilastollinen merkitsevyys testattiin ortogonaalisin kontrastein $(n=15 ; \mathrm{df}=6)$ : Säilöntämenetelmä

$=$ heinä vs. säilörehut, Säilöntäaine $=$ painorehu vs. happorehu.

$* \mathrm{P}<0,05, * * \mathrm{P}<0,01, * * * \mathrm{P}<0,001$, o $\mathrm{P}<0,10$, jos tyhjä $\mathrm{P}>0,10$.

3) Mukana 19:0 